\title{
Аналіз факторів, що впливають на відновлення легеневої функції впродовж фізичної терапії на стаціонарному етапі після кардіохірургічних операцій
}

\author{
УДК 616.12-039-089.8:615.825 \\ В. В. Вітомський
}

Національний університет фізичного виховання і спорту України, Київ, Україна

\begin{abstract}
Резюме. Мета. Виявити та провести аналіз кореляційних зв'язків між динамікою показників спірографії та передопераційними, інтраопераційними факторами. Методи. Аналіз наукової літератури, статистичні дослідження. Результати. Серед передопераційних факторів найбільшу кількість статистично значимих зв'язків з динамікою показників легеневої функції мав вік, проте вони були слабкими. Маса тіла, фракція викиду лівого шлуночка не корелювали з динамікою показників спірографії, а одиничні зв'язки мали довжина тіла та функціональний клас за NYHA. Отримані результати щодо впливу індексу маси тіла на зниження легеневої функції після кардіохірургічних втручань не узгоджуються з попередніми дослідженнями, оскільки встановлено лише два дуже слабких зв'язки. Показник віку мав обернений зв'язок (чим більший вік, тим менше зниження), що також суперечить попереднім висновкам наукових робіт. Динаміка швидкісних показників спірографії мала менше кореляційних зв'язків з передопераційними факторами. Жодний з розглянутих інтраопераційних факторів не мав взаємозв'язків з показниками динаміки пікової об'ємної швидкості вдиху та резервного об'єму видиху. Проведений кореляційний аналіз не встановив зв'язків між тривалістю перетискання аорти, тривалістю штучної вентиляції легень та післяопераційною динамікою показників спірографії. Отримані результати підтвердили вплив кількості шунтів на динаміку показників спірографії, проте зв'язки були дуже слабкими. Проведений аналіз встановив ряд кореляційних зв'язків між динамікою показників спірографії та передопераційними, інтраопераційними факторами, але усі вони були дуже слабкими. Кількість зв'язків з інтраопераційними факторами була більшою. У ряді випадків відсутність зв'язків, їх сила або напрям не узгоджувалися з представленими у літературі факторами ризику післяопераційних легеневих ускладнень, зокрема ступенем серцевої недостатності та віком пацієнта.

Ключові слова: дихання, фізична терапія, реабілітація, кардіореабілітація.
\end{abstract}

Analysis of factors influencing the restoration of pulmonary function during physical therapy in the inpatient phase after cardiac surgery

\section{V. Vitomskyi}

National University of Physical Education and Sport of Ukraine, Kyiv, Ukraine

Abstract. Objective. To identify and analyze the correlations between the dynamics of spirography indicators and preoperative, intraoperative factors. Methods. Analysis of scientific literature, statistical research. Results. Among the preoperative factors, age had the most statistically significant correlations with the dynamics of pulmonary function, but they were weak. Body weight, left ventricular ejection fraction did not correlate with spirography dynamics, and individual relationships had body length and NYHA functional class. The results obtained on the effect of 
body mass index on the reduction of pulmonary function after cardiac surgery are not consistent with previous studies, as only two very weak links have been established. The age indicator was inversely related (the older the age, the smaller the decrease), which also contradicts the previous conclusions of scientific works. Flow dynamics had fewer correlations with preoperative factors. None of the considered intraoperative factors had correlations with the indicators of the dynamics of peak inspiratory flow and expiratory reserve volume. The correlation analysis did not establish a relationship between the duration of aortic compression, the duration of artificial lung ventilation and postoperative dynamics of spirography. The results confirmed the effect of the number of shunts on the dynamics of spirography, but the connections were very weak.

The analysis established a number of correlations between the dynamics of spirography indicators and preoperative, intraoperative factors, but they were all very weak. The number of connections with intraoperative factors was greater. In some cases, the lack of ligaments, their strength or direction were not consistent with the risk factors for postoperative pulmonary complications identified in the literature, including the degree of heart failure and the patient's age.

Keywords: respiration, physical therapy, rehabilitation, cardiorehabilitation.

Постановка проблеми. Пацієнти кардіохірургії $€$ унікальними, оскільки на їх легеневу функцію впливають розріз груднини, місцеве охолодження для захисту міокарда, використання штучного кровообігу та відсічення внутрішньої мамарної артерії [16], що виконується при коронарному шунтуванні. Тому зниження легеневої фрункції після кардіохірургічних втручань (КХВ) $\epsilon$ звичним і очікуваним явищем. Хоча у пацієнтів спостерігається зниження об'ємних і швидкісних показників спірограсрії, післяопераційна легенева дисфункція має рестриктивний характер [12].

Фізична терапія широко використовується для покращення відновлення легеневої фрункції та зменшення післяопераційних легеневих ускладнень (ПЛУ) у кардіохірургічних пацієнтів $[1,5,14]$, зокрема респіраторна, легенева чи торакальна фрізична терапія [2, 15]. Проте $\epsilon$ дослідження, які спростовують різницю в ефективності різних респіраторних методик $[4,6]$, а також корисний ефект від їх використання у програмі фрізичної терапії з метою впливу на легеневу дисфрункцію $[6,8,13]$ та ускладнення $[3,7]$.

Враховуючи це, актуальним $\epsilon$ дослідження інших фракторів, що впливають на післяопераційну динаміку чи відновлення легеневої функції впродовж програми фрізичної терапії на стаціонарному етапі. Дослідники виділяють ряд фракторів, які впливають на виникнення ПЛУ [16], проте вплив на динаміку показників спірографрії залишається недослідженим.

Мета дослідження - виявлення та аналіз кореляційних зв'язків між динамікою показників спірографрії та передопераційними, інтраопераційними фракторами.

Методи дослідження: аналіз наукової літератури, статистичні дослідження.

Результати дослідження. У дослідженні взяли участь 252 пацієнти (медіана віку - 63 роки), яким виконували КХВ у ДУ «Науково-практичний медичний центр дитячої кардіології та кардіохірургії МОЗ України» (Київ). Критерії виключення були аналогічними до представлених у попередній роботі [3]. Пацієнти проходили програму фрізичної терапії (рання мобілізація, лікувальна гімнастика, лікувальна ходьба, респіраторна фрізична терапія), яка детально представлена у попередніх дослідженнях [12]. Роботу виконано 3 дотриманням основних положень Правил етичних принципів проведення наукових медичних досліджень за участю людини, затверджених Гельсінкською декларацією (1964-2013рр.), ICH GCP (1996р.), Директивою ЄEC № 609 від 24.11.1986 р., наказами МОЗ України № 690 від 23.09.2009 р., № 944 від 14.12.2009 р., № 616 від 03.08.2012 р. Всі учасники були інформовані щодо цілей, організації, методів дослідження та підписали інформовану згоду щодо участі у ньому. Було вжито всіх заходів для забезпечення анонімності пацієнтів.

Аналіз історій хвороб проводили для реєстрації передопераційних та інтраопераційних фракторів. Перед операцією та на 7-й післяопераційний день (ПОД) (або раніше, якщо пацієнт виписувався) пацієнтам виконували спірографію 3 використанням спірографра Spirodoc MIR та програмного забезпечення Winspiro PRO. Відсоток від норми розраховували автоматично відповідно до Knudson / European Respiratory Society. Досліджували показники життєвої ємності легень (ЖЄЛ), фоорсованої ЖЄЛ (ФЖЄЛ), об'єму форсованого видиху за першу секунду $\left(О Ф \mathrm{~B}_{1}\right)$, пікової швидкості видиху (ПОШ життєвої ємності легень вдиху (ФЖЄЛ форсованого вдиху за першу секунду $\left(O Ф \mathrm{~B}_{\text {д1 }}\right)$, пікової об'ємної швидкості форсованого вдиху $\left(П О Ш_{в д}\right)$, ємності вдиху $\left(\epsilon_{\text {вд }}\right)$, резервного об'єму видиху $\left(\mathrm{PO}_{\text {вид }}\right)$. Динаміку розраховували шляхом 


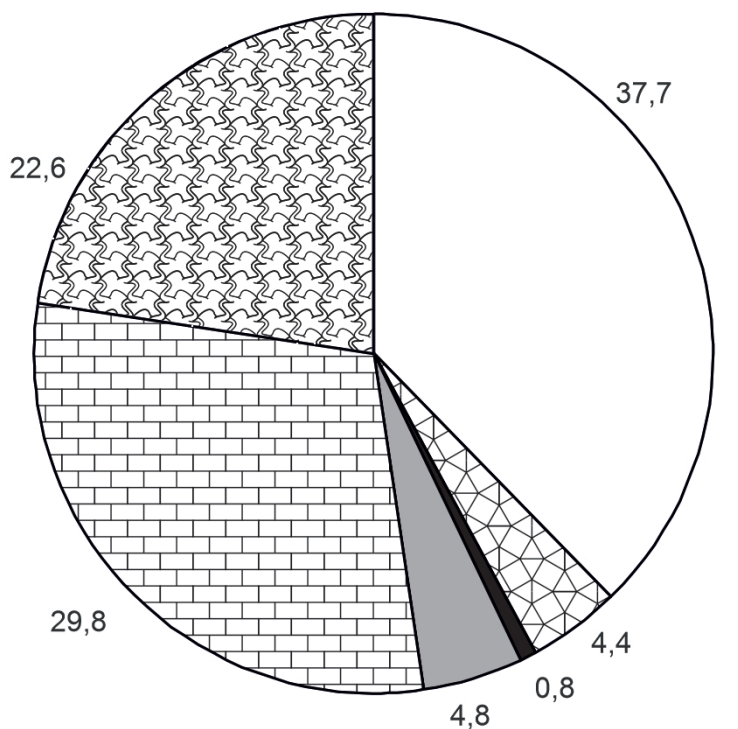

4,8

віднімання результатів першого вимірювання від заключного, що необхідно враховувати при інтерпретації кореляційних зв'язків.

Статистичний аналіз. Використовували прикладну програму IBM SPSS Statistics 21. Відповідність результатів закону нормального розподілу перевіряли за критерієм Шапіро-Вілка. Для результатів показників, що відповідали закону нормального розподілу, розраховували середнє значення та середньоквадратичне відхилення (M $\pm \mathrm{SD})$, а для інших - медіану (Ме) та верхній і нижній квартилі (25\%; 75 \%). Кореляційний аналіз проводили $з$ розрахунком коефіцієнта кореляції Пірсона (r) при відповідності результатів показників закону нормального розподілу чи коефіцієнта рангової кореляції Спірмена (р) в інших випадках.

Серед пацієнтів налічувалося 171 чоловік та 81 жінка. Значення Ме (25 \%; 75 \%) для віку становили 63 (56; 69) роки, для маси тіла - 83 (72; 93) кг, для довжини тіла - 169 (161; 176) см, для фрракції викиду лівого шлуночка - $53(45,3 ; 58) \%$, для систолічного тиску у правому шлуночку серця $30(20 ; 40,8)$ мм рт. ст., для тривалості операції 375 (300; 435) хв, наркозу - 437,5 (370; 510) хв, штучного кровообігу - 180,5 (140,3; 226) хв, перетискання аорти - $122(95 ; 158)$ хв, штучної вентиляції легень - $8(6 ; 11)$ год, мінімальної температури охолодження - $30(30 ; 32){ }^{\circ} \mathrm{C}$. Значення $\mathrm{M} \pm \mathrm{SD}$ для індексу маси тіла становили 29,31 \pm 4,78 кг· м² $^{-2}$. Перший ступінь артеріальної гіпертензії встановлено у $4 \%$ пацієнтів, другий у 42,9\%, а третій - у 38,9\%. Частка пацієнтів 3 першим функціональним класом за NYHA становила 9,9\%, 3 другим - $44 \%$, а з третім - $46 \%$. Ступені серцевої недостатності встановлено: I - у 31,7 \% пацієнтів; ІІА - у 66,3 \%; ІІБ y $1,2 \%$. $\square$ - на клапані(ax)

Х] - на клапані(ax) + мамарне шунтування

- мамарне шунтування

- на клапані(ax) + шунтування з використанням венозного чи/та артеріального графта з периферії

凹- шунтування з використанням венозного чи/та артеріального графта 3 периферії + мамарної артерії

- на клапані(ax) + шунтування 3 використанням венозного чи/та артеріального графта з периферії + мамарне

Рисунок 1 - Розподіл пацієнтів залежно від особливостей операції на серці, \% (n = 252)

Хірургічне втручання на клапані(ах) проводили у $37,7 \%$ пацієнтів, коронарне шунтування - у $30,6 \%$, втручання на клапані(ax) чи/та на аорті 3 коронарним шунтуванням - у 31,7 \%. Більш детальний розподіл пацієнтів представлено на рисунку 1. Передопераційні середні значення ключових показників легеневої функції знаходилися у межах норми, а післяопераційні значення були нижчими від початкових (табл. 1). Відзначимо, що заключну спірографрію проводили в одного пацієнта на 5-й ПОД та в одинадцяти - на 6-й ПОД.

Відзначимо, що індекс маси тіла мав кореляційні зв'язки з передопераційними показниками ЖЕЛ $(r=-0,157 ; p=0,013)$, ОФВ $_{1}(r=-0,136$; $p=0,031), \epsilon_{\text {вд }}(r=0,132 ; p=0,036)$ та $\mathrm{PO}_{\text {вид }}$ $(r=-0,405 ; \mathrm{p}<0,001)$, але не мав зв'язків 3 піковими швидкостями.

За умови позначення пацієнтів чоловічої статі одиницею, а жіночої - двійкою, зі статтю пацієнта встановлено лише два зв'язки з динамікою легеневої функції (табл. 2). При кореляційному аналізі між показниками у підгруп за статтю спостерігалося збільшення або зниження певних коефіцієнтів, зникнення значущості кореляції (у тому числі за рахунок зменшення кількості пацієнтів у підгрупах, зокрема у підгрупі жінок), що може бути підставою для подальших наукових досліджень. Проте не встановлено збільшення коефріцієнтів кореляції до рівня середньої сили зв'язку.

ТАБЛИЦЯ 1 - Показники легеневої функції, \% норми ( $\mathrm{n}=252)$

\begin{tabular}{|c|c|c|}
\hline Показники & До операції & Після операції \\
\hline жєЛ & $101,40 \pm 16,34$ & $74,10 \pm 16,17$ \\
\hline ФЖЄЛ & $100,60 \pm 16,82$ & $73,84 \pm 16,97$ \\
\hline $\mathrm{OФ \textrm {B } _ { 1 }}$ & $101,10 \pm 18,79$ & $75,03 \pm 17,37$ \\
\hline ПОШ вид & $101,54 \pm 20,33$ & $82,62 \pm 21,07$ \\
\hline ФЖЄЛ & $96,39 \pm 18,05$ & $70,59 \pm 16,88$ \\
\hline OФB & $116,30 \pm 22,34$ & $84,97 \pm 20,73$ \\
\hline ПОШ & $71,12 \pm 19,90$ & $59,15 \pm 18,07$ \\
\hline$\epsilon_{\text {вд }}$ & $107,45 \pm 23,70$ & $76,62 \pm 19,80$ \\
\hline $\mathrm{PO}_{\text {вид }}$ & $87,21 \pm 43,37$ & $68,11 \pm 39,14$ \\
\hline
\end{tabular}


ТАБЛИЦЯ 2 - Коефіцієнти рангової кореляції між показниками динаміки легеневої функції та передопераційними факторами

\begin{tabular}{|c|c|c|c|c|c|c|}
\hline \multirow{2}{*}{\multicolumn{2}{|c|}{$\begin{array}{c}\text { Показники } \\
\text { динаміки } \\
\text { легеневої } \\
\text { функції }\end{array}$}} & \multicolumn{5}{|c|}{ Передопераційні фактори } \\
\hline & & \multirow{2}{*}{$\begin{array}{c}\text { вік } \\
-0,157\end{array}$} & \multirow{2}{*}{$\begin{array}{l}\text { стать } \\
0,163 \\
\end{array}$} & \multirow{2}{*}{$\begin{array}{c}\begin{array}{c}\text { індекс } \\
\text { маси } \\
\text { тіла }\end{array} \\
0,110\end{array}$} & \multirow{2}{*}{$\begin{array}{c}\text { систо- } \\
\text { лічний } \\
\begin{array}{c}\text { тиск у } \\
\text { ПШС }\end{array} \\
-0,166\end{array}$} & \multirow{2}{*}{$\begin{array}{c}\begin{array}{c}\text { ступінь } \\
\text { гіперто- } \\
\text { нічної } \\
\text { хвороби }\end{array} \\
0,093\end{array}$} \\
\hline 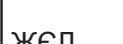 & $\rho$ & & & & & \\
\hline אEJ & $p$ & 0,012 & 0,010 & 0,081 & 0,008 & 0,142 \\
\hline \multirow{2}{*}{ ФЖЄЛ } & $\rho$ & $-0,167$ & 0,102 & 0,111 & $-0,226$ & 0,121 \\
\hline & $p$ & 0,008 & 0,105 & 0,078 & 0,000 & 0,055 \\
\hline \multirow{2}{*}{$\mathrm{O} \Phi \mathrm{B}_{1}$} & $\rho$ & $-0,183$ & 0,113 & 0,128 & $-0,234$ & 0,103 \\
\hline & $p$ & 0,004 & 0,074 & 0,042 & 0,000 & 0,102 \\
\hline \multirow{2}{*}{ ПОШ вид } & $\rho$ & $-0,130$ & $-0,007$ & 0,122 & $-0,090$ & 0,162 \\
\hline & $\mathrm{p}$ & 0,039 & 0,914 & 0,052 & 0,156 & 0,010 \\
\hline \multirow{2}{*}{ ФЖЄЛ } & $\rho$ & $-0,162$ & 0,108 & 0,127 & $-0,160$ & 0,095 \\
\hline & $p$ & 0,010 & 0,087 & 0,044 & 0,011 & 0,134 \\
\hline \multirow{2}{*}{$O \Phi B_{\text {म1 }}$} & $\rho$ & $-0,133$ & 0,055 & 0,072 & $-0,151$ & 0,153 \\
\hline & $p$ & 0,035 & 0,383 & 0,257 & 0,016 & 0,015 \\
\hline \multirow{2}{*}{ ПОШ } & $\rho$ & $-0,206$ & $-0,028$ & 0,043 & $-0,079$ & 0,027 \\
\hline & $\mathrm{p}$ & 0,001 & 0,654 & 0,495 & 0,209 & 0,666 \\
\hline \multirow{2}{*}{$\epsilon_{\text {вд }}$} & $\rho$ & $-0,166$ & 0,019 & 0,114 & $-0,109$ & 0,012 \\
\hline & $p$ & 0,008 & 0,770 & 0,071 & 0,085 & 0,850 \\
\hline \multirow{2}{*}{$\mathrm{PO}_{\text {вид }}$} & $\rho$ & 0,014 & 0,226 & $-0,033$ & $-0,098$ & 0,051 \\
\hline & $p$ & 0,828 & 0,000 & 0,601 & 0,121 & 0,423 \\
\hline
\end{tabular}

Примітка. ПШС - правий шлуночок серця.

Кореляційний аналіз не встановив зв'язків між масою тіла, фракцією викиду лівого шлуночка та післяопераційною динамікою показників спірографії. Крім представлених у таблиці 2 зв'язків, встановлено слабкі взаємозв'язки між довжиною тіла та динамікою $\mathrm{PO}_{\text {вид }}(\rho=-0,132$; $\mathrm{p}=0,036)$; функціональним класом за NYHA та динамікою ПОШ ступенем серцевої недостатності та динамікою ПОШ $(\rho=-0,124 ; p=0,048)$.

Проведений кореляційний аналіз з інтраопераційними фракторами не встановив зв'язків між тривалістю перетискання аорти, тривалістю штучної вентиляції легень та післяопераційною динамікою показників спірографії. Крім представлених у таблиці 3 зв'язків, встановлено слабкі взаємозв'язки між тривалістю штучного кровообігу та динамікою ФЖЄЛ мінімальною температурою охолодження та динамікою ЖЄЛ ( $\rho=-0,136 ; p=0,032)$, динамікою $\epsilon_{\text {вд }}(\rho=-0,127 ; p=0,044)$. Тривалість операції та тривалість наркозу мали найбільшу кількість кореляційних зв'язків, проте вони були слабкими. Кількість клапанів, на яких виконували втручання, корелювала лише з динамікою ОФВ ${ }_{1}(\rho=$ $=-0,136 ; p=0,030)$, а зв'язок був обернений.

Дискусія. Серед передопераційних фракторів найбільшу кількість статистично значимих зв'язків з динамікою показників легеневої функції мав вік, проте вони були слабкими. Маса тіла, фрракція викиду лівого шлуночка не корелювали з динамікою показників спірографії, а одиничні зв'язки мали довжина тіла та фрункціональний клас за NYHA. Динаміка швидкісних показників спірографії мала менше кореляційних зв'язків 3 передопераційними фракторами. Жодний 3 розглянутих інтраопераційних фракторів не мав взаємозв'язків з показниками динаміки ПОШ вд та $\mathrm{PO}_{\text {вид }}$.

Розглянемо отримані результати з огляду на висновки попередніх робіт. Щодо індексу маси тіла, то R. Wynne та M. Botti, посилаючись на інші дослідження, відносять його до передопераційних фракторів ризику ПЛУ [16]. Отримані результати щодо впливу індексу маси тіла на зниження легеневої функції після КХВ не узгоджуються 3 цим висновком, оскільки встановлено лише два дуже слабких зв'язки. Водночас $€$ дослідження, які вказують, що ожиріння не $є$ фрактором ризику [9].

Показник віку мав обернений зв'язок (чим більший вік, тим менше зниження), що також суперечить висновкам огляду, який був виконаний R. Wynne та M. Botti [16]. Аналогічно ступінь серцевої недостатності мав лише один дуже слабкий і обернений зв'язок з показниками динаміки, а фрракція викиду лівого шлуночка взагалі не мала. 3 тривалістю штучного кровообігу встановлено лише один дуже слабкий зв'язок.

3 висновками R. Wynne та M. Botti узгоджуються результати щодо отриманих кореляційних зв'язків між динамікою показників спірографії та кількістю шунтів, проте зв'язки були дуже слабкими. Відзначимо, що виконання коронарного шунтування периореричними судинами та загальна кількість шунтів корелювали з динамікою показників спірографії більш сильно, ніж фракт використання внутрішньої мамарної артерії при шунтуванні. Таким чином, цей фрактор не можна вважати сильним з точки зору впливу на динаміку показників спірографії, хоча попередній літературний огляд [16] включив використання внутрішньої мамарної артерії до фракторів ризику. Втручання на клапанах серця мало обернені зв'язки.

Враховуючи наявні неузгодженості, слід зазначити обставини, які необхідно враховувати при порівнянні отриманих результатів та попередніх: аналізують наявність фрактора чи його тривалість/кількість, фрактори ризику ПЛУ чи фактор зниження результатів спірографрії. 3 іншого боку, визначення і диференціація між нормальним станом та ускладненнями призводять до ве- 
ТАБЛИЦЯ 3 - Коефіцієнти рангової кореляції між показниками динаміки легеневої функції та інтраопераційними факторами $(\mathrm{n}=\mathbf{2 5 2})$

\begin{tabular}{|c|c|c|c|c|c|c|c|c|}
\hline \multirow{2}{*}{\multicolumn{2}{|c|}{$\begin{array}{l}\text { Показники } \\
\text { динаміки } \\
\text { легеневої } \\
\text { функції }\end{array}$}} & \multicolumn{7}{|c|}{ Інтраопераційні фактори } \\
\hline & & \multirow{2}{*}{$\begin{array}{c}\text { час операції } \\
0,137 \\
\end{array}$} & \multirow{2}{*}{\begin{tabular}{|c|} 
час наркозу \\
0,120 \\
\end{tabular}} & \multirow{2}{*}{$\begin{array}{c}\text { кш } \\
0,205 \\
\end{array}$} & \multirow{2}{*}{$\begin{array}{c}\text { КШ мамарне } \\
0,187\end{array}$} & \multirow{2}{*}{$\begin{array}{c}\begin{array}{c}\text { КШ переферичними } \\
\text { судинами }\end{array} \\
0,214 \\
\end{array}$} & \multirow{2}{*}{$\begin{array}{c}\begin{array}{c}\text { втручання на } \\
\text { клапані(ax) }\end{array} \\
-0,132 \\
\end{array}$} & \multirow{2}{*}{$\begin{array}{c}\begin{array}{c}\text { кількість } \\
\text { шунтів }\end{array} \\
0,217 \\
\end{array}$} \\
\hline ЖЕत & $\rho$ & & & & & & & \\
\hline ReJ & $\mathrm{p}$ & 0,030 & 0,057 & 0,001 & 0,003 & 0,001 & 0,037 & 0,001 \\
\hline \multirow{2}{*}{ ФЖЄЛ } & $\rho$ & 0,175 & 0,158 & 0,228 & 0,240 & 0,244 & $-0,192$ & 0,265 \\
\hline & $p$ & 0,005 & 0,012 & 0,000 & 0,000 & 0,000 & 0,002 & 0,000 \\
\hline \multirow{2}{*}{$\mathrm{O} \Phi \mathrm{B}_{1}$} & $\rho$ & 0,153 & 0,142 & 0,222 & 0,234 & 0,246 & $-0,202$ & 0,263 \\
\hline & $p$ & 0,015 & 0,025 & 0,000 & 0,000 & 0,000 & 0,001 & 0,000 \\
\hline \multirow{2}{*}{ ПОШ вид } & $\rho$ & 0,162 & 0,179 & 0,076 & 0,041 & 0,108 & $-0,018$ & 0,103 \\
\hline & $p$ & 0,010 & 0,004 & 0,231 & 0,518 & 0,087 & 0,780 & 0,103 \\
\hline \multirow{2}{*}{ ФЖЄЛ } & $\rho$ & 0,222 & 0,202 & 0,213 & 0,203 & 0,204 & $-0,098$ & 0,217 \\
\hline & $p$ & 0,000 & 0,001 & 0,001 & 0,001 & 0,001 & 0,119 & 0,001 \\
\hline \multirow{2}{*}{$\mathrm{O} Ф \mathrm{~B}_{\mathrm{A} 1}$} & $\rho$ & 0,180 & 0,178 & 0,181 & 0,200 & 0,211 & $-0,110$ & 0,214 \\
\hline & $p$ & 0,004 & 0,005 & 0,004 & 0,001 & 0,001 & 0,081 & 0,001 \\
\hline \multirow[b]{2}{*}{$\epsilon_{\text {вд }}$} & $\rho$ & 0,098 & 0,114 & 0,178 & 0,151 & 0,198 & $-0,086$ & 0,202 \\
\hline & $p$ & 0,123 & 0,070 & 0,005 & 0,016 & 0,002 & 0,174 & 0,001 \\
\hline
\end{tabular}

Примітка. КШ - коронарне шунтування.

ликої варіативності частоти ПЛУ - від 5 до $90 \%$ [11]. Водночас, незважаючи на поширеність цих ускладнень у кардіохірургічних пацієнтів, розпізнавання, діагностика та лікування цієї проблеми дуже різняться. Крім того, мало інформації про відмінності між рутинною післяопераційною легеневою дисфункцією та ПЛУ [16]. Отримані кореляційні зв'язки та їх сила узгоджуються 3 висновками попередніх досліджень про те, що причини післяопераційної легеневої диссрункції залишаються невизначеними та $є$ багатофракторними [10]. Відзначається, що пов'язані з легеневою диссункцією процеси після КХВ ще не досліджені [16].

\section{Література}

1. Вітомський ВВ, Аль-Хавамдех ХМ, Лазарєва ОБ, Вітомська МВ. Фізична терапія пацієнтів після кардіохірургічних втручань: аналіз опитувань фізичних терапевтів різних країн [Physical therapy of patients after cardiosurgery]. Спортивна медицина, фізична терапія та ерготерапія. 2020;(2):62-72. https://doi.org/10.32652/spmed.2020.2.62-72

2. Вітомський ВВ, Аль-Хавамдех ХМ. Роль респіраторної фізичної терапії у відновному лікуванні пацієнтів після кардіохірургічних втручань [The Role of Respiratory Physical Therapy in the Rehabilitation of Patients after Cardiac Surgery]. Український журнал медицини, біології та спорту. 2020;5(4):17-25. https://doi.org/10.26693/jmbs05.04.017

3. Вітомський ВВ. Вплив респіраторної фізичної терапії на рівень вільної рідини у плевральних порожнинах після кардіохірургічних втручань [The Effect of Respiratory Physical Therapy on the Level of Free Fluid in Pleural Cavities after Cardiac Surgery]. Український журнал медицини, біології та спорту. 2021;6(2):189-95. https://doi.org/10.26693/jmbs06.02. 189

4. Вітомський ВВ. Порівняння впливу стимулюючої спірометрії та інспіраторних м'язових тренувань на відновлення легеневої функції після кардіохірургічних втручань [Comparison of the impact of stimulatory
Висновки. Проведений аналіз встановив ряд кореляційних зв'язків між динамікою показників спірографрії та передопераційними, інтраопераційними фракторами, але усі вони були дуже слабкими. Кількість зв'язків з інтраопераційними фракторами була більшою. У ряді випадків відсутність зв'язків, їх сила або напрям не узгоджувалися з представленими у літературі факторами ризику післяопераційних легеневих ускладнень, зокрема ступенем серцевої недостатності та віком пацієнта, що може пояснюватися відмінністю між рутинною післяопераційною легеневою дисфункцією та післяопераційним ускладненням.

spirometry and inspiratory muscle training on pulmonary function restoration of cardiosurgery]. Україна. Здоров'я нації. 2021;1(2):96-100. https://doi. org/10.24144/2077-6594.2.1.2021.235372

5. Вітомський ВВ. Рання мобілізація кардіохірургічних пацієнтів: перешкоди виконання, протоколи та ефективність [Early mobilization of cardiosurgical patients: performance barriers, protocols and efficiency]. Art of Medicine. 2020;2:131-6.

6. Dull JL, Dull WL. Are maximal inspiratory breathing exercises or incentive spirometry better than early mobilization after cardiopulmonary bypass? Physical Therapy. 1983;63(5):655-9

7. Jenkins S, Akinkugbe Y, Corry G, Johnson L. Physiotherapy management following coronary artery surgery. Physiotherapy Theory and Practice. 1994;10(1):3-8.

8. Jenkins SC, Soutar SA, Loukota JM, Johnson LC, Moxham J. A comparison of breathing exercises, incentive spirometry and mobilisation after coronary artery surgery. Physiotherapy Theory and Practice. 1990;6(3):117-26.

9. Moulton MJ, Creswell LL, Mackey ME, Cox JL, Rosenbloom M. Obesity is not a risk factor for significant adverse outcomes after cardiac surgery. Circulation. 1996;94(9 suppl):II87-II92. 
10. Schuller D, Morrow LE. Pulmonary complications after coronary revascularization. Curr Opin Cardiol. 2000 Sep;15(5):309-15.

11. Urell C, Emtncr M, Hedenstrom H, Westerdahl E. Respiratory muscle strength is not decreased in patients undergoing cardiac surgery. $\mathrm{J}$ Cardiothorac Surg. 2016;11:41. https://doi.org/10.1186/s|3019-016-0433-z.

12. Vitomskyi V, Al-Hawamdeh K, Vitomska M, Lazarieva O, Haidai O. The effect of incentive spirometry on pulmonary function recovery and satisfaction with physical therapy of cardiac surgery patients. Advances in Rehabilitation. 2021;35(1):9-16. doi:10.5114/areh.2020.102020.

13. Vitomskyi V. Comparison of three respiratory physical therapy techniques and their impact on pulmonary function restoration among cardiac surgery patients in hospital settings. Zaporozhye medical journal. 2021;23(4): 531-5. https://doi.org/10.14739/2310-1210.2021.4.226538

14. Vitomskyi V. The impact of mobilization and other factors on pleural effusion in patients undergoing cardiac surgical procedures. Journal of Physical Education and Sport. 2020;20(Supplement issue 3):2167-73.

15. Westerdahl E, Olsén MF. Chest physiotherapy and breathing exercises for cardiac surgery patients in Sweden - a national survey of practice. Monaldi Arch Chest Dis. 2011 Jun;75(2):112-9.

16. Wynne R, Botti M. Postoperative pulmonary dysfunction in adults after cardiac surgery with cardiopulmonary bypass: clinical significance and implications for practice. Am J Crit Care. 2004 Sep;13(5):384-93. 